\title{
ANALISIS PENGARUH KECERDASAN EMOSIONAL PEMIMPIN, KEPUASAN DAN LINGKUNGAN ORGANISASI TERHADAP LOYALITAS PENGURUS ORGANINASI MAHASISWA FAKULTAS EKONOMI UNIVERSITAS AHMAD DAHLAN
}

\author{
Fatoni Imam Wibowo \\ fatoni990@yahoo.com \\ Universitas Ahmad Dahlan \\ Utik Bidayati \\ utikbidayati@yahoo.com \\ Universitas Ahmad Dahlan
}

\begin{abstract}
ABSTRAK
This study aims to determine the effect of emotional intelligence leaders, satisfaction, and organizational environment both partially and together towards the loyalty of the management of the Faculty Student Organization Economics of Ahmad Dahlan University Yogyakarta 2014/2015 period. This research is a quantitative research. Data collection with using a questionnaire method (questionnaire) that has been tested for validity and reliability, while data analysis is done using analysis multiple linear regression. The subjects of this research are all organizational management there are 153 students of the Faculty of Economics with engineering sampling using purposive sampling method, so the amount the sample used was 106 administrators. The results showed that: 1) Emotional intelligence of leaders no significant effect on the loyalty of the board. 2) Satisfaction no significant effect on the loyalty of the board. 3) Organizational environment positive and significant effect on the loyalty of the board shown from the results of the $t$ test of 2.163 with a significance of 0.033. 4) Intelligence emotional leaders, satisfaction, and organizational environment together significant effect on the loyalty of the board, this is indicated from the results $\mathrm{F}$ test count of 12.273 with a significance of 0,000 and can be written with regression equation $\mathrm{Y}=$ $-1,431+0,126 X 1+0,181 X 2+0,276 X 3$. With big influence of $26.5 \%$, while the remaining $73.5 \%$ is influenced by other independent variables are not observed.
\end{abstract}

Keywords: Emotional Intelligence Leader; Satisfaction; Environment Organization; Loyalty.

\section{PENDAHULUAN}

Salah satu sumber daya yang terdapat dalam organisasi ialah sumber daya manusia. Sumber daya manusia memiliki akal, pikiran, perasaan, keinginan, kemampuan, ketrampilan, pengetahuan, daya, dorongan, karya, inovasi, kreasi, dan harapan. Sumber daya manusia merupakan bagian dari organisasi yang berperan penting karena berfungsi sebagai roda penggerak utama dari seluruh kegiatan atau aktivitas organisasi. Sumber daya manusia akan mampu
Meningkatkan efektifitas dan efisiensi kerja dalam organisasi, sehingga diperlukan pengelolaan yang baik dalam organisasi. Organisasi bergantung pada kualitas sumber daya manusia dan fasilitas yang mendukung dalam aktivitas organisasinya.

Marpaung (2012) menyebutkan bahwa kecerdasan emosional pemimpin adalah serangkaian kemampuan baik verbal maupun nonverbal yang dimilki seorang pemimpin untuk menciptakan, mengenal, mengekspresikan, memahami, dan mengevaluasi emosional. Orang-orang 
yang mengenal emosi-emosi mereka sendiri dan mampu dengan baik membaca emosi orang lain dapat menjadi lebih efektif dalam pekerjaan mereka. Ditemukan bahwa kualitas penting yang membedakan yang berhasil seperti Roosevelt, Kennedy, dan Reagan dari yang tidak berhasil seperti Johnson, Carter, dan Nixon adalah kecerdasan emosional.

Kreitner (2005) mendefinisikan kepuasan kerja adalah suatu efektivitas atau respons emosional terhadap berbagai aspek pekerjaan. Definisi ini berarti bahwa kepuasan kerja bukanlah suatu konsep tunggal. Sebaliknya, seorang dapat relatif puas dengan suatu aspek dari pekerjaannya dan tidak puas dengan salah satu atau lebih aspek lainnya.

Kesuma (2007) dalam Paratama 2013) menyatakan suatu lingkungan kerja yang aman dan nyaman dapat meningkatkan kinerja karyawan dan sebaliknya lingkungan kerja yang kurang aman dan nyaman dapat menurunkan kinerja karyawan. Organisasi mahasiswa pun demikian, lingkungan organisasi sangat mempengaruhi kinerja maupun loyalitas pengurus. Semakin aman dan nyaman lingkungan yang ada diorganisasi maka semakin tinggi semangat untuk bekerja dan memberikan yang terbaik untuk organisasi tersebut.

Antoncic (2011) dalam Marpaung (2012) mengatakan bahwa loyalitas adalah apabila karyawan memiliki kesadaran dan tanpa paksaan untuk berkomitmen menjalankan tanggung jawab dan berupaya memberikan kinerja mereka yang terbaik bagi perusahaan. Untuk mendapatkan loyalitas dari pengurusnya maka organisasi harus senantiasa menjaga keharmonisan dalam semua aktivitasnya.

Jika di dalam perusahaan disebut karyawan, maka di dalam Organisasi Mahasiswa akan disebut dengan pengurus. Organisasi Mahasiswa di Fakultas Ekonomi Universitas Ahmad Dahlan yang merupakan tempat berkumpulnya para mahasiswa dari setiap program studi baik Manajemen, Akuntansi, dan Ekonomi Pembangunan yang saling bekerja sama satu dengan yang lain. Organisasi Mahasiswa yang dituntut memiliki pengurus dengan loyalitas tinggi untuk membangun kerja sama yang baik antar pengurus-pengurus, pengurus-ketua, dan pengurus untuk organisasi sehingga mampu menghasilkan kinerja yang terbaik dan mampu membantu organisasi dalam mencapai tujuan organisasi. Fenomena perputaran atau perpindahan pengurus yang ada di Organisasi Mahasiswa pun terlihat masih sangat besar, walaupun batas maksimal dari waktu kepengurusan belum usai. Loyalitas pengurus dibutuhkan karena pencapaian tujuan organisasi dapat dilakukan secara berkesinambungan oleh setiap generasi. Kecerdasan emosional yang baik dari seorang pemimpin, kepuasan yang diberikan oleh organisasi, dan lingkungan yang ada di organisasi merupakan beberapa faktor yang mempengaruhi loyalitas pengurus di organisasi. Dengan adanya kecerdasan emosional pemimpin, kepuasan, dan lingkungan organisasi maka dapat dilihat pengaruhnya dari loyalitas pengurus.

Tujuan dari penelitian ini di antaranya: 1) untuk mengetahui pengaruh kecerdasan emosional pemimpin terhadap loyalitas pengurus Organisasi Mahasiswa Fakultas Ekonomi, 2) untuk mengetahui pengaruh kepuasan terhadap loyalitas pengurus Organisasi Mahasiswa Fakultas Ekonomi, 3) untuk mengetahui pengaruh lingkungan organisasi terhadap loyalitas pengurus Organisasi Mahasiswa Fakultas Ekonomi dan 4) untuk mengetahui pengaruh kecerdasan emosional pemimpin, kepuasan, dan lingkungan organisasi secara bersama-sama terhadap loyalitas pengurus Organisasi Mahasiswa Fakultas Ekonomi. 


\section{REVIEW LITERATUR DAN} HIPOTESIS

\section{Landasan Teori}

\section{Organisasi}

Budiyanto (2013) menjelaskan organisasi secara etimologi berasal dari kata organon dalam bahasa Yunani yang berarti alat, menurut Kamus Besar Bahasa Indonesia, organisasi adalah susunan dan aturan dari berbagai-bagai bagian (orang dsb) sehingga merupakan kesatuan yang teratur.

2. Manajemen Sumber Daya Manusia

Sule (2005) mendefinisikan bahwa manajemen sumber daya manusia adalah penerapan manajemen berdasarkan fungsinya untuk memperoleh sumber daya manusia yang terbaik bagi bisnis yang kita jalankan dan bagaimana sumber daya manusia yang terbaik tersebut dapat dipelihara dan tetap bekerja bersama kita dengan kualitas pekerjaan yang senantiasa konstan ataupun bertambah.

\section{Kecerdasan Emosional Pemimpin}

Marpaung (2012) menyebutkan bahwa kecerdasan emosional pemimpin adalah serangkaian kemampuan baik verbal maupun nonverbal yang dimilki seorang pemimpin untuk menciptakan, mengenal, memahami, dan mengevaluasi emosional.

4. Kepuasan Kerja

Martoyo (2000) mendefinisikan kepuasan kerja adalah keadaaan emosional karyawan dimana terjadi ataupun tidak terjadi titik temu antara nilai balas jasa kerja karyawan dari perusahaan atau organisasi dengan tingkat nilai jasa yang memang diinginkan oleh karyawan yang bersangkutan.

\section{Lingkungan Kerja}

Robbins (2008) menyatakan lingkungan (environment) sebuah organisasi terbentuk dari lembagalembaga atau kekuatan-kekuatan diluar organisasi yang berpotensi memperngaruhi kinerja organisasi.

6. Loyalitas

Robbins (2008) menyatakan kesetiaan (loyalty) secara pasif tetapi optimistis menunggu membaiknya kondisi, termasuk membela organisasi ketika berhadapan dengan kecaman eksternal dan memercayai organisasi dan manajemennya untuk "melakukan hal yang benar".

\section{Penelitian Terdahulu}

"Pengaruh kompensasi dan lingkungan kerja terhadap loyalitas karyawan pada PT. Jatim Jaya Perkasa Kebun Banjar Balam Indragiri Hulu" dalam jurnal JOM FEKON (Maineldi, 2014). Menunjukan bahwa thitung $(4,428)$ $>\mathrm{t}$ tabel $(1,985)$ dan signifikansi $(0,000)$ $<0,05$, sehingga disimpulkan lingkungan kerja berpengaruh signifikan terhadap loyalitas karyawan Pada PT Jatim Jaya Perkasa Kebun Banjar Balam Indragiri Hulu.

"Pengaruh Leader Member Exchange (LMX), Motivasi Kerja, dan Kepuasan Kerja Terhadap Loyalitas Karyawan Departemen Penjualan CV. Pratama Jaya di Madiun" dalam jurnal AGORA (Wibowo, 2013). Menunjukan bahwa nilai signifikan dari kepuasan kerja adalah $0,001<0,05, \quad$ sehingga disimpulkan bahwa Kepuasan kerja memiliki pengaruh positif dan signifikan terhadap loyalitas karyawan CV. Pratama Jaya.

"Pengaruh Kecerdasan Emosional Pemimpin terhadap Kinerja danLoyalitas Karyawan di PT Riau Andalan Pulp and Paper Bisnis Unit Riau Fiber" dalam jurnal aplikasi (Marpaung, 2012). Menunjukan 
bahwa thitung lebih besar dari ttabel $(3,628>1,97718)$ atau signifikansi $t$ lebih kecil dari $5 \% \quad(0,000<0,05)$, sehingga disimpulkan bahwa variabel Kecerdasan Emosional Pemimpin berpengaruh signifikan terhadap variabel Loyalitas.

\section{Hipotesis}

H1: Ada pengaruh kecerdasan emosional pemimpin terhadap loyalitas pengurus Organisasi Mahasiswa Fakultas Ekonomi Universitas Ahmad Dahlan.

H2: Ada pengaruh kepuasan terhadap loyalitas pengurus Organisasi Mahasiswa Fakultas Ekonomi Universitas Ahmad Dahlan.

H3: Ada pengaruh lingkungan organisasi terhadap loyalitas pengurus Organisasi Mahasiswa Fakultas Ekonomi Universitas Ahmad Dahlan.

H4: Ada pengaruh kecerdasan emosional pemimpin, kepuasan, dan lingkungan organisasi secara bersama-sama terhadap loyalitas pengurus Organisasi Mahasiswa Fakultas Ekonomi Universitas Ahmad Dahlan.

\section{METODE PENELITIAN}

\section{Populasi dan Sampel}

Sugiyono (2011) menyatakan bahwa populasi adalah wilayah generalisasi yang terdiri atas obyek atau subyek yang mempunyai kualitas dan karakteristik tertentu yang ditetapkan oleh peneliti untuk dipelajari dan kemudian ditarik kesimpulannya. Populasi dalam penelitian ini adalah seluruh pengurus Organisasi Mahasiswa Fakultas Ekonomi periode 2014/2015 sebanyak 153 mahasiswa.

Sugiyono (2011) menyatakan bahwa sampel adalah bagian dari jumlah dan karakteristik yang dimiliki oleh populasi tersebut. Dalam penelitian ini sampel yang diambil adalah pengurus Organisasi Mahasiswa Fakultas Ekonomi yang sedang menempuh semester tiga dan semester lima, sebanyak 106 mahasiswa terdiri dari 9 pengurus DPM, 14 pengurus BEM, 20 pengurus HMPSM, 16 pengurus HMPS-A, dan 47 pengurus HMPS-EP.

\section{Definisi Operasional}

1. Variabel Independen

a. Kecerdasan Emosional Pemimpin (X1)

Kecerdasan emosional pemimpin adalah setiap pemimpin atau ketua Organisasi Mahasiswa Fakultas Ekonomi mampu untuk mengontrol segala bentuk emosi yang dimiliki dalam dirinya sehingga dampak yang timbul dari emosinya merupakan hal positif. Indikator kecerdasan emosional pemimpin dalam penelitian ini meliputi kesadaran diri, manajemen diri, motivasi diri, empati, dan keterampilan sosial.

b. Kepuasan (X2)

Kepuasan adalah suatu respons emosional dari seorang pengurus kepada ketua organisasi ataupun organisasinya dalam berbagai aspek kegiatan. Indikator kepuasan dalam penelitian ini meliputi aktivitas organisasi, kesempatan mengembangkan diri, dan ketua organisasi.

c. Lingkungan Organisasi (X3)

Lingkungan organisasi adalah segala sesuatu yang ada di setiap Organisasi Mahasiswa dan yang dapat mempengaruhi pengurus dalam menajalankan tugas maupun tanggung jawabnya. Indikator lingkungan organisasi dalam penelitian ini meliputi kondisi di organisasi, hubungan antar personal, suasana aktivitas. 
2. Variabel Dependen

Variabel dependen yang digunakan dalam penelitian ini adalah loyalitas pengurus (Y). Loyalitas pengurus adalah komitmen dan kesetiaan pengurus kepada Organisasi Mahasiswa Fakultas Ekonominya masing-masing dalam melakukan segala tanggung jawab yang diberikan dan berupaya memberikan kinerja yang terbaik untuk organisasinya. Dalam penelitian ini variabel loyalitas pengurus dapat diukur menggunakan indikator berkarir di organisasi, mengenal organisasi, Kebanggaan sebagai bagian dari organisasi, dan disiplin.

\section{Uji Instrumen}

\section{Uji Validitas}

Instrumen yang valid berarti alat ukur yang digunakan untuk mendapatkan data (mengukur) itu valid. Sugiyono (2011) menyatakan bahwa valid berarti instrumen tersebut dapat digunakan untuk mengukur apa yang seharusnya diukur.

\section{Uji Reliabilitas}

Sugiyono (2011) menyatakan bahwa instrumen yang reliabel adalah instrumen yang bila digunakan beberapa kali untuk mengukur objek yang sama, akan menghasilkan data yang sama. Jadi instrumen yang valid dan reliabel merupakan syarat mutlak untuk mendapatkan hasil penelitian yang valid dan reliabel. Instrumen yang reliabel belum tentu valid. Oleh karena itu, walaupun instrumen yang valid umumnya pasti reliabel, tetapi pengujian reliabilitas instrumen perlu dilakukan.

\section{Teknik Analisis Data}

1. Analisis Regresi Berganda

Sugiyono (2011) menyatakan dalam penelitian kuantitatif, analisis data merupakan kegiatan setelah data dari seluruh responden atau sumber data lain terkumpul. Kegiatan dalam analisis data adalah mengelompokkan data berdasarkan variabel dan jenis responden, mentabulasi data berdasarkan variabel dari seluruh responden, menyajikan data tiap variabel yang diteliti, melakukan perhitungan untuk menguji hipotesis yang telah diajukan. Untuk penelitian yang tidak merumuskan hipotesis, langkah terakhir tidak dilakukan.

Analisis regresi linear berganda digunakan oleh peneliti untuk meramalkan bagaimana keadaan (naik turunnya) variabel dependen, bila dua atau lebih vaiabel independen sebagai faktor prediktor dimanipulasi (dinaik turunkan nilainya). Untuk dapat meramalkan bagaimana loyalitas pengurus bila kecerdasan emosional pemimpin, kepuasan, dan lingkungan organisasi dinaikkan atau diturunkan, maka penulis menggunakan bantuan program software SPPS 20. Persamaan garis regresi yang digunakan :

$$
Y=\beta_{0}+\beta_{1} X_{1}+\beta_{2} X_{2}+\beta_{3} X_{3}
$$

Dimana :

$$
\begin{array}{ll}
\mathrm{Y} & =\text { Loyalitas pengurus } \\
\beta_{0} & =\text { Konstanta } \\
\beta_{1}-\beta_{3} & =\text { Koefisien regresi } \\
\mathrm{X}_{1} & =\text { Kecerdasan emosional pemimpin } \\
\mathrm{X}_{2} & =\text { Kepuasan } \\
\mathrm{X}_{3} & =\text { Lingkungan organisasi }
\end{array}
$$

\section{Uji Hipotesis}

\section{Uji Parsial (Uji T)}

Uji $\mathrm{t}$ digunakan untuk mengetahui signifikansi pengaruh variabel independen secara individu terhadap variabel dependen untuk 
menyatakan menolak atau menerima hipotesis.

Jika t hitung > t tabel maka, H0 ditolak dan Ha diterima.

Jika $\mathrm{t}$ hitung $<\mathrm{t}$ tabel maka, H0 diterima dan Ha ditolak.

Jika nilai sign. > alpha maka, H0 diterima dan Ha ditolak.

Jika nilai sign. < alpha maka, H0 ditolak dan Ha diterima.

\section{Uji Simultan (Uji F)}

Uji F digunakan untuk menghitung signifikansi pengaruh variabel independen secara bersamasama terhadap variabel dependen.

Jika $\mathrm{F}$ hitung > F tabel maka, H0 ditolak dan Ha diterima.

Jika F hitung < F tabel maka, H0 ditolak dan Ha diterima.

Jika nilai sign. > alpha maka, H0 diterima dan Ha ditolak.

Jika nilai sign. < alpha maka, H0 ditolak dan Ha diterima.

\section{Uji Koefisien Determinasi}

$$
\text { Zain (2006) menyatakan }
$$

koefisien determinasi (R2) seperti didefinisikan seperti mengukur kebaikan (goodness of fit) dari persamaan regresi yaitu memberikan proporsi atau persentase variasi total dalam variabel tak bebas $Y$ yang dijelaskan oleh variabel yang menjelaskan $X$. Gagasan mengenai R2dapat diperluas untuk model regresi yang berisi lebih dari dua variabel. Nilai koefisien determinasi adalah antara 0 (nol) sampai 1 (satu).

\section{HASIL PENELITIAN DAN PEMBAHASAN}

\section{Hasil Penelitian}

1. Hasil Uji Validitas

Hasil Uji Validitas Variabel Kecerdasan Emosional Pemimpin
\begin{tabular}{|c|c|c|}
\hline Nomor & Pernyataan & Keputusan \\
\hline 1 & Pernyataan 1 & Tidak Valid \\
\hline 2 & Pernyataan 2 & Tidak Valid \\
\hline 3 & Pernyataan 3 & Valid \\
\hline 4 & Pernyataan 4 & Valid \\
\hline 5 & Pernyataan 5 & Tidak Valid \\
\hline 6 & Pernyataan 6 & Valid \\
\hline 7 & Pernyataan 7 & Tidak Valid \\
\hline 8 & Pernyataan 8 & Tidak Valid \\
\hline 9 & Pernyataan 9 & Tidak Valid \\
\hline 10 & Pernyataan 10 & Valid \\
\hline 11 & Pernyataan 11 & Valid \\
\hline 12 & Pernyataan 12 & Valid \\
\hline 13 & Pernyataan 13 & Valid \\
\hline 14 & Pernyataan 14 & Tidak Valid \\
\hline 15 & Pernyataan 15 & Tidak Valid \\
\hline
\end{tabular}

Tabel di atas menunjukan bahwa pernyataan-pernyatan variabel kecerdasan emosional pemimpin yang terdiri dari Q3, Q4, Q6, Q10, Q11, Q12, dan Q13 merupakan penyataan yang valid, sedangkan Q1, Q2, Q5, Q7, Q8, Q9, Q14, dan Q15 merupakan pernyataan yang tidak valid dan dinyatakan gugur. Penyataan yang telah valid akan diajukan kepada responden yang tersisa sebanyak 76 responden, namun di dalamnya tidak terdapat pernyataan yang mewakili dari indikator motivasi diri karena ketiga penyataan yang mewakili indikator motivasi diri telah gugur dalam pengujian validitas yaitu Q7, Q8, dan Q9. 
Hasil Uji Validitas Variabel Kepuasan

\begin{tabular}{|c|c|c|}
\hline Nomor & Pernyataan & Keputusan \\
\hline 1 & Pernyataan 1 & Valid \\
\hline 2 & Pernyataan 2 & Valid \\
\hline 3 & Pernyataan 3 & Tidak Valid \\
\hline 4 & Pernyataan 4 & Tidak Valid \\
\hline 5 & Pernyataan 5 & Valid \\
\hline 6 & Pernyataan 6 & Valid \\
\hline 7 & Pernyataan 7 & Valid \\
\hline 8 & Pernyataan 8 & Valid \\
\hline
\end{tabular}

Tabel di atas menunjukan bahwa penyataan-penyatan kepuasan yang terdiri dari Q1, Q2, Q5, Q6, Q7, dan Q8 merupakan penyataan yang valid, sedangkan Q3 dan Q4 merupakan pernyataan yang tidak valid dan dinyatakan gugur. Penyataan yang telah valid akan diajukan kepada responden yang tersisa sebanyak 76 responden.

Hasil Uji Validitas Variabel Lingkungan Organisasi

\begin{tabular}{|c|c|c|}
\hline Nomor & Pernyataan & Keputusan \\
\hline 1 & Pernyataan 1 & Valid \\
\hline 2 & Pernyataan 2 & Valid \\
\hline 3 & Pernyataan 3 & Valid \\
\hline 4 & Pernyataan 4 & Valid \\
\hline 5 & Pernyataan 5 & Valid \\
\hline 6 & Pernyataan 6 & Valid \\
\hline 7 & Pernyataan 7 & Valid \\
\hline 8 & Pernyataan 8 & Valid \\
\hline 9 & Pernyataan 9 & Tidak Valid \\
\hline 10 & Pernyataan 10 & Tidak Valid \\
\hline
\end{tabular}

Tabel di atas menunjukan bahwa penyataan-penyatan lingkungan organisasi yang terdiri dari Q1, Q2, Q3, Q4, Q5, Q6, Q7, dan Q8 merupakan penyataan yang valid, sedangkan Q9 dan Q10 merupakan pernyataan yang tidak valid dan dinyatakan gugur. Penyataan yang telah valid akan diajukan kepada responden yang tersisa sebanyak 76 responden.
Hasil Uji Validitas Variabel Loyalitas

\begin{tabular}{|c|c|c|}
\hline Nomor & Pernyataan & Keputusan \\
\hline 1 & Pernyataan 1 & Valid \\
\hline 2 & Pernyataan 2 & Valid \\
\hline 3 & Pernyataan 3 & Valid \\
\hline 4 & Pernyataan 4 & Valid \\
\hline 5 & Pernyataan 5 & Valid \\
\hline 6 & Pernyataan 6 & Tidak Valid \\
\hline 7 & Pernyataan 7 & Tidak Valid \\
\hline 8 & Pernyataan 8 & Tidak Valid \\
\hline 9 & Pernyataan 9 & Tidak Valid \\
\hline 10 & Pernyataan 10 & Tidak Valid \\
\hline
\end{tabular}

Tabel di atas menunjukan bahwa penyataan-penyatan loyalitas anggota yang terdiri dari Q1, Q2, Q3, Q4, dan Q5 merupakan penyataan yang valid, sedangkan Q6, Q7, Q8, Q9, dan Q10 merupakan pernyataan yang tidak valid dan dinyatakan gugur. Penyataan yang telah valid akan diajukan kepada responden yang tersisa sebanyak 76 responden.

2. Hasil Uji Reliabilitas

\begin{tabular}{|c|r|r|r|}
\hline Variabel & $\begin{array}{r}\text { Cronbach } \\
\text { Alpha }(\boldsymbol{\alpha})\end{array}$ & $\begin{array}{c}\text { Alpha } \\
(\text { Konstruk) }\end{array}$ & Keputusan \\
\hline Kecerdasan Emosional Pemimpian & 0,828 & 0,60 & Reliabel \\
\hline Kepuasan & 0,657 & 0,60 & Reliabel \\
\hline Lingkungan Organisasi & 0,703 & 0,60 & Reliabel \\
\hline Loyalitas Pengurus & 0,847 & 0,60 & Reliabel \\
\hline
\end{tabular}

Berdasarkan hasil uji reliabilitas diatas, maka dapat diketahui nilai koefisien Cronbach Alpha $(\alpha)$ pada masing-masing varibelnya > 0,60 sehingga dapat disimpulkan bahwa semua pernyataan dalam penelitian ini adalah reliabel dan dapat digunakan untuk penelitian selanjutnya. 
3. Hasil Uji Regresi Linier Berganda Hasil Analisis Regresi Linear Berganda

\begin{tabular}{|l|c|c|c|}
\hline \multicolumn{1}{|c|}{ Variabel } & Koefisien & t test & Sign. \\
\hline Konstanta emosional & 0,126 & 1,133 & 0,260 \\
\hline Kecerdasan & & & \\
pemimpin & & & \\
\hline Kepuasan & 0,181 & 1,286 & 0,201 \\
\hline Lingkungan organisasi & 0,276 & 2,163 & 0,033 \\
\hline F test & $12,273 \longrightarrow$ sign. 0,000 \\
\hline R Square & 0,265 & 0,000 & 1,000 \\
\hline
\end{tabular}
$\mathrm{Y}=-1,431+0,126 X 1+0,181 X 2+$ $0,276 X 3$

Nilai Konstanta $=-1,431$ artinya apabila semua variabel penjelas adalah nol maka nilai $\mathrm{Y}$ akan sama dengan nilai konstantanya yaitu sebesar 1,431. Penjelasan variabel dari persamaan diatas adalah:

a. Variabel kecerdasan emosional pemimpin (X1) yang mempunyai nilai koefisien $=0,126$ yang berarti setiap kenaikan variabel kecerdasan emosional pemimpin sebesar 1 tingkat, maka loyalitas pengurus akan naik sebesar 0,126 dengan asumsi variabel yang lain tetap.

b. Variabel kepuasan (X2) yang mempunyai nilai koefisien = 0,181yang berarti setiap kenaikan variabel kepuasan sebesar 1 tingkat, maka loyalitas pengurus akan naik sebesar 0,181 dengan asumsi variabel yang lain tetap.

c. Variabel lingkungan organisasi (X3) yang mempunyai nilai koefisien $=0,276$ yang berarti setiap kenaikan variabel lingkungan organisasi sebesar 1 tingkat, maka loyalitas pengurus akan naik sebesar 0,276 dengan asumsi variabel yang lain tetap.

\section{Hasil Uji Parsial (Uji T)}

a. Hipotesis Pertama (X1)

Hasil pengujian signifikansi antara variabel kecerdasan emosional pemimpin dengan loyalitas pengurus Organisasi Mahasiswa Fakultas Ekonomi. Dari uji hipotesis pada tingkat kepercayaan atau $\alpha=0,05$ dan derajat kebebasan $=104$, diperoleh hasil t hitung1,133 sedangkan t tabel 1,659. Dilihat dari perhitungan tersebut menunjukkan bahwa $\mathrm{t}$ hitung $=1,133<\mathrm{t}$ tabel $=1,659$ berarti bahwa variabel kecerdasan emosional pemimpin tidak berpengaruh terhadap loyalitas pengurus Organisasi Mahasiswa Fakultas Ekonomi atau terima H0.

Hal ini juga dapat dilihat dari nilai sign. hitung $=0,260>$ alpha $(\alpha)$ $=0,05$ yang berarti bahwa kecerdasan emosional pemimpin tidak berpengaruh terhadap loyalitas pengurus Organisasi Mahasiswa Fakultas Ekonomi atau terima H0.

b. Hipotesis Kedua (X2)

Hasil pengujian signifikansi antara variabel kepuasan dengan loyalita pengurus Organisasi Mahasiswa Fakultas Ekonomi. Dari uji hipotesis pada tingkat kepercayaan atau $\alpha=0,05$ dan derajat kebebasan $=104$, diperoleh hasil $\mathrm{t}$ hitung 1,286 sedangkan $\mathrm{t}$ tabel 1,659. Dilihat dari perhitungan tersebut menunjukkan bahwa $t$ hitung $=1,286<\mathrm{t}$ tabel $=1,659$ berarti bahwa variabel kepuasan tidak berpengaruh terhadap loyalitas pengurus Organisasi Mahasiswa Fakultas Ekonomi atau terima H0.

Hal ini juga dapat dilihat dari nilai sign. hitung $=0,201>$ alpha $(\alpha)$ $=0,05$ yang berarti bahwa kepuasan tidak berpengaruh terhadap loyalitas pengurus Organisasi Mahasiswa Fakultas Ekonomi atau terima H0. 
c. Hipotesis Ketiga (X3)

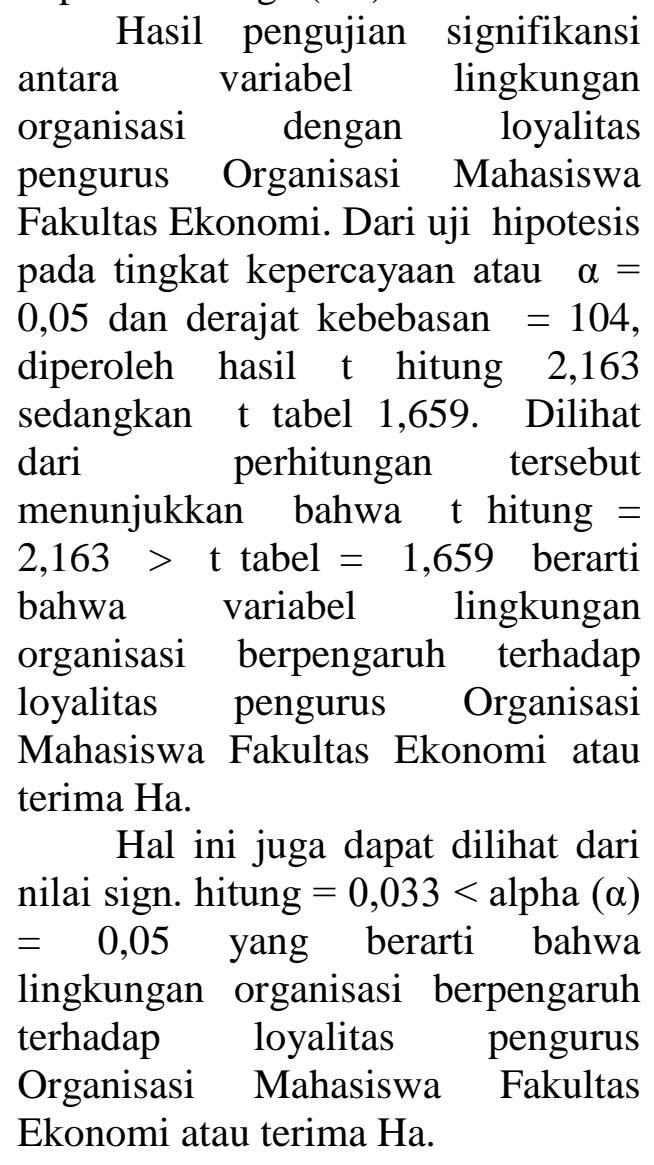

\section{Hasil Uji Simultan (Uji F)}

Hasil pengujian signifikansi antara variabel kecerdasan emosional pemimpin, kepuasan, dan lingkungan organisasi dengan loyalitas pengurus Organisasi Mahasiswa Fakultas Ekonomi. Dari uji hipotesis pada tingkat kepercayaan atau $\alpha=0,05$ dan derajat kebebasan $=104$, diperoleh hasil $\mathrm{F}$ hitung 12,273 sedangkan F tabel 2,69. Dilihat dari perhitungan tersebut menunjukkan bahwa $\mathrm{F}$ hitung $=12,273>\mathrm{F}$ tabel $=2,69$ berarti bahwa variabel kecerdasan emosional pemimpin, kepuasan, dan lingkungan organisasi secara bersama-sama berpengaruh terhadap loyalitas pengurus Organisasi Mahasiswa Fakultas Ekonomi atau terima Ha.

Hal ini juga dapat dilihat dari nilai sign. hitung $=0,000<$ alpha $(\alpha)=0,05$ yang berarti bahwa kecerdasan emosional pemimpin, kepuasan, dan lingkungan organisasi secara bersama- sama berpengaruh terhadap loyalitas pengurus Organisasi Mahasiswa Fakultas Ekonomi atau terima Ha.

\section{Hasil Uji Koefisien Determinasi}

Dari perhitungan menggunakan software SPSS 20 menunjukan bahwa koefisien determinan (R2) mempunyai nilai sebesar 0,265. Hal ini berarti bahwa 26,5\% dari loyalitas pengurus Organisasi Mahasiswa Fakultas Ekonomi Universitas Ahmad Dahlan dapat dijelaskan oleh variabel kecerdasan emosional pemimpin, kepuasan, dan lingkungan organisasi sebagai variabel bebas, sedangkan sisanya sebanyak $73,5 \%$ dari variabel terikat yaitu loyalitas pengurus diterangkan oleh variabel bebas lain yang tidak diamati.

\section{Pembahasan}

Dari penelitian yang dilakukan, diperoleh hasil bahwa kecerdasan emosional pemimpin tidak mempunyai pengaruh yang signifikan terhadap loyalitas pengurus. Pada variabel kecerdasan emosional pemimpin (X1) memiliki koefisien regresi sebesar 0,126 yang berarti jika pemimpin atau ketua Organisasi Mahasiswa Fakultas Ekonomi memiliki kesadaran diri, manajemen diri, motivasi diri, empati, dan keterampilan sosial dalam dirinya sebesar 1 satuan maka akan meningkatkan loyalitas pengurus sebesar 0,216. Hasil ini kurang sesuai dengan penelitian Marpaung (2012) yang menyatakan bahwa kecerdasan emosional pemimpin berpengaruh terhadap loyalitas. Kecerdasan emosional pemimpin dari ketua Organisasi Mahasiswa Fakultas Ekonomi baik dari DPM, BEM, HMPS-M, HMPS-A, dan HMPS-EP masih harus diperbaiki dan ditingkatkan dari segala hal terutama dalam motivasi diri dari seorang ketua organisasi dalam semua aktivitas atau kegiatan diorganisasinya. Kesadaran diri, manajemen diri, empati, dan keterampilan sosial pun harus ditingkatkan oleh 
ketua organisasi. Peran ketua organisasi yang mampu mengarahkan dan menjadikan anggotanya loyal pada organisasinya sangat penting untuk pencapaian tujuan dari organisasi tersebut cepat tercapai secara berkesinambungan.

Untuk variabel kepuasan (X2) diperoleh hasil bahwa koefisien regresi sebesar 0,181 yang berarti jika pengurus Organisasi Mahasiswa Fakultas Ekonomi merasa senang beraktivitas di organisasinya, dapat kesempatan mengembangkan diri, dan selaras dengan ketua organisasi dalam dirinya sebesar 1 satuan maka akan meningkatkan loyalitas pengurus sebesar 0,181. Hasil ini kurang sesuai dengan penelitian Wibowo (2013) yang menunjukan bahwa kepuasan kerja karyawan departemen penjualan berpengaruh terhadap loyalitas karyawan departemen penjualan. Kepuasan untuk internal organisasi ataupun eksternal organisasi masih belum terpenuhi untuk setiap pengurus dalam masing-masing organisasi, sehingga perlunya ada pembenahan dan perbaikan terutama dalam hal aktivitas di organisasi, kesempatan mengembangkan diri di organisasi menjadi lebih besar, dan keselarasan dengan ketua organisasi menjadi semakin padu untuk menghasilkan pengurus dengan jiwa loyalitas dari masing-masing organisasi.

Untuk variabel lingkungan organisasi (X3) diperoleh hasil bahwa koefisien regresi sebesar 0,276 yang berarti jika pengurus Organisasi Mahasiswa Fakultas Ekonomi nyaman dengan kondisi di organisasi, hubungan antar personal yang terjalin dengan baik, dan suasana aktivitas di organisasi yang menyenangkan dalam diri maupun organisasinya sebesar 1 satuan maka akan meningkatkan loyalitas pengurus sebesar 0,276 . Hasil ini sesuai dengan penelitian dari Maineldi, (2014) yang menunjukan hasil bahwa lingkungan kerja berpengaruh signifikan terhadap loyalitas karyawan Pada PT Jatim Jaya Perkasa Kebun Banjar Balam Indragiri Hulu. Hasil tersebut menunjukkan lingkungan organisasi berpengaruh positif dan signifikan terhadap loyalitas pengurus, artinyadengan semakin baiknya lingkungan organisasi maka akan meningkatkan loyalitas pengurus Organisasi Mahasiswa Fakultas Ekonomi. Oleh karena itu, lingkungan organisasi harus selalu ada peningkatan baik dari organisasinya maupun hubungan didalam organisasi sehingga loyalitas pengurus semakin tinggi terhadap organisasi.

Untuk variabel kecerdasan emosional pemimpin (X1), kepuasan (X2), dan lingkungan organisasi (X3) secara bersama-sama berpengaruh signifikan terhadap loyalitas pengurus Organisasi Mahasiswa Fakultas Ekonomi. Pengaruh yang timbul adalah positif yaitu semakin baik kecerdasan emosional pemimpin, kepuasan pengurus dalam organisasi, dan lingkungan organisasi akan semakin tinggi pula tingkat loyalitas pengurus untuk organisasinya masing-masing. Banyak faktor yang mempengaruhi loyalitas pengurus dalam proses aktivitas dalam organisasinya, kecerdasan emosional pemimpin, kepuasan, dan lingkungan organisasi secara bersamasama menyumbang sebesar $26.5 \%$ dalam penentuan apakah seorang pengurus memiliki loyalitas yang tinggi atau rendah terhadap organisasinya.

Dari hasil analisis didapat bahwa seorang ketua organisasi harus memiliki kecerdasan emosional yang baik dalam memimpin rekan-rekannya dan mampu menciptakan kepuasan anggota baik dalam internal organisasi maupun secara personal. Lingkungan organisasi yang diciptakan oleh semua pengurus dan pemimpin pun sangat berpengaruh dalam menentukan loyalitas pengurus untuk menjadikan kinerja dan semangat pengurus dalam beraktivitas di organisasi semakin tinggi sehingga pencapaian tujuan organisasi cepat tercapai. Organisasi yang memiliki pemimpin dengan kecerdasan emosional yang baik, kepuasan yang besar di internal organisasi 
maupun antar personal, dan lingkungan organisasi yang mendukung maka organisasi tersebut akan memiliki pengurus-pengurus dengan rasa loyalitas (kesetiaan) yang tinggi.

\section{KESIMPULAN DAN SARAN}

\section{Kesimpulan}

1. Kecerdasan Emosional Pemimpin tidak berpengaruh signifikan terhadap Loyalitas Pengurus Organisasi Mahasiswa Fakultas Ekonomi Universitas Ahmad Dahlan periode 2014-2015. Hal tersebut ditunjukkan dari hasil uji t hitung sebesar 1,133 dengan signifikansi 0,260.

2. Kepuasan tidak berpengaruh signifikan terhadap Loyalitas Pengurus Organisasi Mahasiswa Fakultas Ekonomi Universitas Ahmad Dahlan periode 2014-2015. Hal tersebut ditunjukkan dari hasil uji t hitung sebesar 1,286 dengan signifikansi 0,201.

3. Lingkungan Organisasi berpengaruh positif dan signifikan terhadap Loyalitas Pengurus Organisasi Mahasiswa Fakultas Ekonomi Universitas Ahmad Dahlan periode 2014-2015. Hal tersebut ditunjukkan dari hasil uji t hitung sebesar 2,163 dengan signifikansi 0,033 .

4. Kecerdasan Emosional Pemimpin, Kepuasan, dan Lingkungan Organisasi secara bersama-sama berpengaruh signifikan terhadap Loyalitas Pengurus Organisasi Mahasiswa Fakultas Ekonomi Universitas Ahmad Dahlan periode 2014-2015. Hal tersebut ditunjukkan dari hasil uji $\mathrm{F}$ hitung sebesar 12,273 dengan signifikansi 0,000 .
Kemampuan model variabel independen yaitu Kecerdasan Emosional Pemimpin, Kepuasan, dan Lingkungan Organisasi dalam menerangkan variasi variabel dependen yaitu Loyalitas Pengurus sebesar $26,5 \%$, sedangkan $73,5 \%$ dijelaskan diterangkan oleh variabel bebas lain yang tidak diamati.

\section{Saran}

1. Bagi Organisasi Mahasiswa Fakultas Ekonomi

a. Sumber daya manusia yang ada di dalam organisasi ataupun penunjang lainnya yang berkaitan dengan aktivitas di organisasi harus selalu ditingkatkan untuk menghasilkan kinerja yang terbaik dari setiap sumber daya manusia dan jiwa loyalitas dalam organisasi tersebut.

b. Organisasi maupun ketua organisasi diharapkan selalu menjaga suasana dan kondisi yang tetap nyaman serta harmonis dalam lingkungan organisasinya, sehingga terjalin kerjasama yang baik untuk seluruh komponen dalam organisasi.

\section{Bagi Peneliti Mendatang}

a. Penelitian dimasa yang akan datang sebaiknya memperluas variabel dan pengukuran variabel penelitian sehingga tingkat loyalitas pengurus Organisasi Mahasiswa Fakultas Ekonomi dapat lebih baik lagi.

b. Sampel untuk mengukur loyalitas yang sebenarnya diharapkan pengurus yang telah bergabung minimal dengan masa jabatan 2 periode mulai dari semester 1 atau 3 sampai dengan semester 5 dan 7 .

c. Populasi dan sampel yang diambil dipenelitian selanjutnya diharapkan dapat lebih luas hingga tingkat Universitas. 


\section{DAFTAR PUSTAKA}

Budiyanto, Eko. (2013). Sistem Informasi Manajemen Sumber Daya Manusia. Edisi Pertama. Yogyakarta: Graha Ilmu.

Kreitner, Robert dan Angelo Kinicki. (2005). Perilaku Organisasi Organizational Behavior. Edisi kelima. Jakarta: Salemba Empat.

Maineldi, Andromike, Susi Hendriani dan Iwan Nauli Daulay. (2014). Pengaruh kompensasi dan lingkungan kerja terhadap loyalitas karyawan pada PT. Jatim Jaya Perkasa Kebun Banjar Balam Indragiri Hulu. Jurnal JOM FEKON, Vol. 1, No.2. Pekanbaru: Fakultas Ekonomi Universitas Riau.

Marpaung, Rio. (2012). Pengaruh Kecerdasan Emosional Pemimpin terhadap Kinerja dan Loyalitas Karyawan di PT Riau Andalan Pulp and Paper Bisnis Unit Riau Fiber. Jurnal Aplikasi Manajemen, Vol. 11, No. 3. Pekanbaru: Fakultas Ekonomi Universitas Riau.

Martoyo, Susilo. (2000). Manajemen Sumber Daya Manusia. Edisi Empat. Yogyakarta: BPFE.

Paratama, Putu Ivan Ady dan I Wayan Mudiartha Utama. (2013). Pengaruh Penempatan Dan Pengalaman Kerja Serta Lingkungan Kerja Terhadap Loyalitas Karyawan. Jurnal. Bali: Fakultas Ekonomi Universitas Udayana.

Robbins, Stephen P. dan Timothy A. Judge. (2008). Perilaku Organisasi Organizational Behavior. Buku 1 edisi 12. Jakarta: Salemba Empat.
Sugiyono. (2011). Metode Penelitian Kombinasi (Mixed Methods). Bandung: Alfabeta.

Sule, Ernie Tisnawati dan Kurniawan Saefullah. (2005). Pengantar Manajemen. Edisi pertama. Jakarta: Kencana Prenada Media Group.

Wibowo, Jeffry dan Eddy M. Sutanto. 2013. Pengaruh Leader Member Exchange (Lmx), Motivasi Kerja Dan Kepuasan Kerja Terhadap Loyalitas Karyawan Departemen Penjualan Cv. Pratama Jaya Di Madiun. Jurnal AGORA. Vol. 1. No.3. Surabaya: Program Studi Manajemen Universitas Kristen Petra.

Zain, Sumarno. (2006). Ekonometrika Dasar. Jakarta: Erlangga. 